\title{
Analisis Kemampuan Berfikir Kritis Mahasiswa PGSD Dalam Menyelesaikan Soal Matematika Dasar
}

Suriyana ${ }^{1}$, Risdiana Andika Fatmawati ${ }^{2}$

1)Program Studi Pendidikan Matematika;Fakultas Keguruan dan Ilmu Pendidikan; Universitas Nahdlatul Ulama Kalimantan Barat ; anna.0222sakharie@gmail.com 2)Program Studi PGSD; Fakultas Keguruan dan Ilmu Pendidikan; Universitas Nahdlatul Ulama Kalimanatan Barat ; risdianaandika005@gmail.com

Abstrak. Penelitian ini bertujuan untuk menganalisis kemampuan berfikir kritis mahasiswa PGSD dalam menyelesaikan soal matematika pada matakuliah Matematika dasar. Subjek penelitian ini adalah mahasiswa Prodi PGSD yang berjumlah 20 mahasiswa, 16 mahasiswa perempuan dan 4 laki-laki. Proses pengumpulan data dilakukan melalui tes tulis berupa tes kemampuan berfikir kritis dan wawancara. Penelitian ini merupakan penelitian kualitatif karena data yang diperoleh dianalisis secara deskriptif berdasarkan ketercapaian indikator berfikir kritis pada setiap soal. Hasil analisis data penelitian menunjukkan bahwa kemampuan berpikir kritis pada indikator menganalisis argumen kategori kurang. Kemampuan berpikir kritis pada indikator mengevaluasi informasi kategori tidak baik. Kemampuan berpikir kritis pada indikator mensintesis bukti kategori tidak baik. Kemampuan berpikir kritis pada indikator menarik kesimpulan kategori tidak baik. Sehingga kesimpulan dari penelitian ini adalah kemampuan berpikir kritis mahasiswa PGSD perlu untuk dikembangkan.

Kata Kunci: Kemampuan Berfikir Kritis, Matematika Dasar

Abstract. This research aims to analyze the critical thinking skills at student of PGSD in solving of math problems in basic Mathematics courses. The subjects of this study were 20 students of PGSD Study Program, 16 female students and 4 male students. The process of collecting data is done through written tests in the form of tests of critical thinking skills and interviews. This research is a qualitative research because the data obtained were analyzed descriptively based on the achievement of critical thinking indicators on each question. The results of the analysis of research data show that the ability to think critically on the indicator analyzes the arguments in the less category. The ability to think critically on indicators evaluating information in categories is not good. The ability to think critically on indicators synthesizes evidence of bad categories. The ability to think critically on indicators draw

Caruban: Jurnal Ilmiah Pendidikan Dasar 2(2), 84-101, Juli 2019

p-ISSN 2615-1391, e-ISSN 2620-3219 @Prodi PGSD Universitas Swadaya Gunung Jati 
conclusions that are not good. So the conclusion of this research is that the critical thinking skills of PGSD students need to be developed.

\section{Pendahuluan}

Pada kurikulum pendidikan nasional Indonesia, mata pelajaran matematika selalu diajarkan dalam disetiap jenjang pendidikan, tidak kecuali di perguruan tinggi. Hal ini menunjukkan bahwa eksistensi matematika sangat tinggi dalam dunia pendidikan. Di era revolusi industri menuju 4.0 seperti sekarang ini, dibutuhkan sumber daya manusia yang kompetitif sehingga mampu menghadapi tuntutan perkembangan jaman yang semakin maju. Kualitas sumber daya manusia suatu bangsa ditentukan oleh tingkat pendidikan bangsa tersebut. Pendidikan memegang peranan penting karena pendidikan merupakan wahana untuk meningkatkan dan mengembangkan kualitas sumber daya manusia. Dalam dunia pendidikan, matematika merupakan salah satu mata pelajaran yang sangat penting karena matematika merupakan ilmu yang dapat melatih seseorang untuk berpikir kritis. Matematika juga memiliki struktur dan keterkaitan yang kuat dan jelas antar konsepnya, sehingga memungkinkan peserta didik terampil berpikir rasional. Mengingat hal tersebut, penting untuk mempelajari matematika tidak hanya sekedar mengetahui tetapi juga berusaha untuk memahami dan bisa mengaplikasikannya dalam persoalan yang lain.

Kemampuan berpikir kritis merupakan kemampuan yang perlu dikembangkan dalam dunia pendidikan. Hal tersebut sesuai dengan "Partnership for 21st Century Skills" yang mengidentifikasi bahwa berpikir kritis merupakan salah satu dari inovasi keterampilan yang diperlukan dalam rangka menyiapkan mahasiswa untuk pendidikan selanjutnya maupun tenaga kerja (Lai, 2011). Menurut Ennis (2013), Kemampuan berpikir kritis diperlukan dalam membuat keputusan untuk melakukan atau mempercayai suatu hal yang diawali dengan berpikir dengan beralasan dan berpikir reflektif. Berpikir kritis berkaitan erat dengan Matematika, khususnya dalam me-nyelesaikan permasalahan. Namun berdasarkan pengamatan para lulusan tidak memiliki kompetensi yang cukup dalam penguasaan materi matematika dan 
menunjukkan kelemahan dalam berpikir kritis, Oleh karena itu, berpikir kritis perlu didorong dan diperkuat pada semua jenjang pendidikan terutama pada mahasiswa Prodi PGSD.

Berdasarkan urgensi dan fakta mengenai kemampuan berpikir kritis mahasiswa, maka dosen perlu melakukan upaya untuk meningkatkan kemampuan berfikir kritis tersebut. Namun sebelum dilakukan upaya peningkatan kemampuan berpikir kritis mahasiswa, terlebih dahulu dosen melakukan analisis mengenai kemampuan berpikir kritis mahasiswa. Oleh karena itu diperlukan suatu penelitian yang bertujuan untuk menganalisis kemampuan berpikir kritis mahasiswa. Adapun yang menjadi subjek penelitian ini yakni mahasiswa S1 Program Studi PGSD Universitas Nahdlatul Ulama Kalimantan Barat semester 2 yang berjumlah 20 orang.

\section{Kemampuan Berpikir Kritis}

Paul Ernest dalam Rasiman (3:2011) mendefinisikan berpikir kritis sebagai kemampuan membuat kesimpulan berdasarkan pada observasi dan informasi. Menurut Beyer dalam Rasiman (3:2011) juga menggambarkan berpikir kritis sebagai kegiatan menilai dengan akurat, kepercayaan dan dengan menggunakan argumen atau secara singkat ia menyatakan bahwa berpikir kritis adalah tindakan yang dilakukan seseorang dalam membuat penilaian dengan penalaran yang baik. Menurut Ennis berpikir kritis adalah berpikir secara beralasan dan reflektif dengan menekankan pada pembuatan keputusan tentang apa yang harus dipercayai atau dilakukan (Hassoubah, 2004: 13).

Indikator kemampuan berpikir kritis menurut Ennis (Hassoubah, 2004:14) terdapat dua belas indikator kemampuan berpikir kritis yang dikelompokkan dalam lima kelompok keterampilan berpikir, yaitu: 1) Memberikan penjelasan sederhana, meliputi: a) Memfokuskan pertanyaan, peserta didik fokus terhadap pertanyaan yang diberikan oleh peneliti, b) Menganalisis pertanyaan, c) Bertanya dan menjawab pertanyaan tentang suatu penjelasan atau tantangan. 2) Membangun keterampilan dasar, meliputi: a) Mempertimbangkan kriteria dan keabsahan informasi, b) Mengamati dan mempertimbangkan suatu laporan observasi, c) Menyimpulkan, d) Mendeduksi dan mempertimbangkan hasil induksi, artinya menyimpulkan suatu 
permasalahan dari umum ke khusus, e) Menginduksi dan mempertimbangkan hasil induksi, artinya menyimpulkan suatu permasalahan dari khusus ke umum. f) Membuat dan menentukan nilai pertimbangan. 3) Memberikan penjelasan lanjut, meliputi: a) Mendefiniskan istilah dan definisi pertimbangan dalam tiga dimensi, b) Mengidentifikasi asumsi, yaitu memeriksa kembali pendapat anggota kelompok yang telah disimpulkan sebelum dipresentasikan. 4) Mengatur strategi dan taktik, meliputi: a) Menentukan tindakan, b) Berinteraksi dengan orang lain.

Kemampuan berpikir kritis setiap individu berbeda antara satu dengan lainnya sehingga perlu dipupuk sejak dini. Berpikir terjadi dalam setiap aktivitas mental manusia berfungsi untuk mencari solusi dari masalah, membuat keputusan serta mencari alasan. Sesorang yang berpikir kritis memiliki karakter khusus yang dapat diidentifikasi dengan melihat bagaimana seseorang menyikapi suatu masalah. Informasi atau argument karakter-karakter tersebut tampak pada kebiasaan bertindak, beragumen dan memanfaatkan intelektual dan pengetahuannya. Berpikir kritis memuat keterampilan menganalisis, mensin-tesis argumen, mengevaluasi informasi, me-narik kesimpulan menggunakan penalaran deduktif dan induktif, dan menyelesaikan permasalahan (Lai, 2011).

Berdasarkan pengertian dan komponen berpikir kritis, indikator berpikir kritis yang digunakan pada penelitian ini yaitu keterampilan menganalisis argumen yaitu kemampuan mahasiswa untuk memahami apa yang diketahui pada permasalahan dan mengetahui apa yang ditanyakan pada setiap permasalahan yang disediakan, mengevaluasi informasi yaitu kemampuan setiap mahasiswa untuk menuliskan konsep yang digunakan dari permasalahan yang disediakan, mensintesis bukti kemampuan setiap mahasiswa untuk menuliskan keterangan simbol dari model matematika yang telah ditentukan, dan menarik kesimpulan yaitu kemampuan mahasiswa untuk menyelesaikan permasalahan yang yang telah disediakan dengan menggunakan konsep dan model matematika yang telah ditentukan dan mampu memberikan kesimpulan dari permasalahan itu. 
Rubenfeld dan Scheffer (5: 2006) menjelaskan faktor yang mempengaruhi seseorang pemikir kritis adalah genetika, konsep diri, ansietas, dan emosional lain, serta kultur, termasuk warisan keluarga dan budaya, masyarakat dan budaya organisasi.

Adapun beberapa faktor yang mempengaruhi berpikir kritis seseorang menurut pendapat ahli lainnya, diantaranya: 1) Kondisi Fisik: menurut Maslow dalam Siti Mariyam (4:2007) kondisi fisik adalah kebutuhan fisiologi yang paling dasar bagi manusia untuk menjalani kehidupan. Ketika kondisi fisik siswa terganggu, sementara ia dihadapkan pada situasi yang menuntut pemikiran yang matang untuk memcahkan suatu masalah maka kondisi seperti ini sangat mempengaruhi pikirannya. Ia tidak dapat berkonsentrasi dan berpikir cepat karena tubuhnya tidak memungkinkan untuk bereaksi terhadap respon yang ada. 2) Motivasi: motivasi merupakan hasil faktor internal dan eksternal. Motivasi adalah upaya untuk menimbulkan rangsangan, dorongan ataupun pembangkit tenaga seseorang agar mau berbuat sesuatu atau memperlihatkan perilaku tertentu yang telah direncanakan untuk mencapai tujuan yang telah ditetapkan. Menciptakan minat adalah cara yang sangat baik untuk member motivasi pada diri demimencapai tujuan. Motivasi yang sangat tinggi terlihat dari kemampuan atau kapasitas atau daya serap dalam belajar, mengambil resiko, menjawab pertanyaan, menentang kondisi yang tidak mau berubah kearah yang lebih baik, mempergunakan kesalahan sebagai kesimpulan belajar, semakin cepat memperoleh tujuan dan kepuasan, memperlihatkan tekad diri, sikap kontruktif, memperlihatkan hasrat dan keingintauan, serta kesediaan untuk menyetujui hasil perilaku. 3) Kecemasan: keadaan emosional yang ditandai dengan kegelisahan dan ketakutan terhadap kemungkinan bahaya. Kecemasan timbul secara otomatis jika individu menerima stimulus berlebih yang melampaui untuk menanganinya (internal, eksternal). Reaksi terhadap kecemasan dapat bersifat;a) konstruktif, memotivasi individu untuk belajar dan mengadakan perubahan terutama perubahan perasaan tidak nyaman, serta terfokus pada kelangsungan hidup; b) destruktif, menimbulkan tingkah laku maladaptive dan disfungsi yang menyangkut kecemasan berat atau panic serta dapat membatasi seseorang dalam berpikir. 4) 
Perkembangan Intelektual: intelektual atau kecerdasan merupakan kemampuan mental seseorang untuk merespon dan menyelesaikan suatu persoalan, menghubungkan suatu hal dengan yang lain dan dapat merespon dengan baik setiap stimulus. Perkembangan intelektual tiap orang berbedabeda disesuaikan dengan usia dan tingkah perkembangannya, semakin bertambah umur anak, semakin tampak jelas kecenderungan dalam kematangan proses.

\section{Matematika Dasar}

Matematika berasal dari bahasa Yunani, mathein atau manthenein yang berarti mempelajari. (Sri Subarinah,2006:1). Matematika adalah disiplin ilmu yang mempelajari tentang tata cara berpikir dan mengolah logika, baik secara kuantitatif maupun secara kualitatif (Erman Suherman, 2003:298). Depdiknas (2006: 346) matematika meliputi aspek-aspek bilangan, aljabar, geometri dan pengukuran serta statistika dan peluang.

Matematika merupakan ilmu universal yang mendasari perkembangan teknologi modern, mempunyai peran penting dalam berbagai disiplin dan memajukan daya pikir manusia (Depdiknas, 2006:147). Matematika adalah suatu alat untuk mengembangkan cara berpikir, karena itu matematika sangat diperlukan baik untuk memecahkan masalah dalam kehidupan sehari-hari maupun untuk menunjang kemajuan ilmu pengetahuan dan teknologi (Offirston, 2014:1). Dengan demikian maka sangat penting mempelajari matematika untuk mempersiapkan mahasiswa agar mampu menggunakan pola pikir matematika dalam kehidupan kesehariannya dan dalam mempelajari ilmu pengetahuan lainnya.

Matematika dasar merupakan matakuliah yang terdapat pada jenjang perguruan tinggi. Pada prodi PGSD nama matakuliah untuk mengajarkan mahasiswa tentang matematika dasar adalah Konsep Dasar Matematika. Materi konsep dasar matematika diantaranya adalah operasi bilangan, bangun datar, bangun ruang, perbandingan. Dalam penelian ini materi yang digunakan dalam penyusunan soal kemampuan berpikir kritis adalah materi bangun datar kesebangunan.

\section{Metode Penelitian}


Metode yang digunakan dalam penelitian ini adalah metode kualitatif. Subjek dari penelitian ini adalah mahasiswa semeter 2 Program Studi PGSD UNU Kalbar yang sedang menempuh mata kuliah konsep dasar matematika. Pemilihan subjek penelitian disadari oleh beberapa pertimbangan, yaitu: (a) Mahasiswa semester 2 sedang menempuh mata kuliah konsep dasar matematika yang merupakan dasar dari mata kuliah matematika lanjutan, sehingga melalui analisis kemampuan berpikir kritis ini dapat memberikan informasi kepada dosen untuk dapat meningkatkan pembelajaran matematika tingkat lanjut. (b) Mudah memberikan informasi terkain kesulitan-kesulitan ketika menyelesaikan soal tes.

Teknik pengumpulan data dalam penelitian ini menggunakan tes. Tes yang dipergunakan berupa tes uraian yang berjumlah lima soal, bertujuan untuk mendapatkan data kemampuan berpikir kritis matematis. Tes diberikan pada pertengahan perkuliahan mata kuliah Matematika Keuangan (pada saat kuis). Tes dibuat berdasarkan indikator kemampuan berpikir kritis matematis yaitu: (1) kemampuan menganalisis argumen, (2) kemampuan mengevaluasi informasi, (3) kemampuan mensintesis bukti, (4) kemampuan menarik kesimpulan.

Data hasil penelitian dianalisis secara deskriptif kualitatif untuk mengetahui kemampuan berpikir kritis pada mata kuliah konsep dasar Matematika mahasiswa yang diteliti. Dalam analisis data juga dikemukakan kemampuan berpikir kritis matematis mahasiswa untuk setiap indikator kemampuan berpikir kritis matematis yang diteliti. Nilai tes mahasiswa secara keseluruhan dikonversikan ke dalam kategori penilaian berdasarkan modifikasi dari Sugiono seperti pada tabel di bawah ini.

Tabel 1. Kategori Skala 3.1

\begin{tabular}{lll}
\hline Skala & & Kategori \\
Indeks & $\mathbf{0} \%-\mathbf{1 9 , 9 9 \%}$ & Sangat Tidak Baik \\
Indeks & $\mathbf{2 0} \%-39,99 \%$ & Tidak Baik \\
\hline
\end{tabular}

Caruban: Jurnal Ilmiah Pendidikan Dasar 2(2), 84-101, Juli 2019

p-ISSN 2615-1391, e-ISSN 2620-3219 CProdi PGSD Universitas Swadaya Gunung Jati 


\begin{tabular}{lll}
\hline Indeks & $40 \%-59,99 \%$ & Kurang Baik \\
Indeks & $60 \%-79,99 \%$ & Baik \\
Indeks & $80 \%-100 \%$ & Sangat Baik
\end{tabular}

Sumber: Sugiono (2013:134)

\section{Hasil Penelitian dan Pembahasan}

Data hasil penelitian kemampuan berpikir kritis mahasiswa diperoleh dari hasil penyelesaian soal-soal evaluasi sebanyak lima soal. Soal-soal dibuat berdasarkan indikator kemampuan berpikir kritis yang diberikan kepada 20 mahasiswa. Data yang sudah diperoleh kemudian dianalisis menggunakan rubrik ketercapaian indikator kemampuan berpikir kritis yang dilakukan pada setiap soal. Berikut adalah adalah analisis ketercapaian indikator berpikir kritis pada soal nomor 1 yang disajikan pada tabel berikut:

Tabel 2. Hasil Ketercapaian Indikator Berpikir Kritis pada Soal 1

\begin{tabular}{llll}
\hline No & $\begin{array}{l}\text { Indikator } \\
\text { Keemampuan } \\
\text { Perpikir } \\
\text { Kritis }\end{array}$ & $\begin{array}{l}\text { Jumlah } \\
\text { ketercapaian }\end{array}$ & Keterangan \\
& $(\%)$ & \\
\hline 1 & Menganalisis & $55 \%$ & Kurang \\
& argumen & & Baik \\
2 & $\begin{array}{l}\text { Mengevaluasi } \\
\text { Informasi }\end{array}$ & $45 \%$ & Kurang \\
& & Baik \\
\hline
\end{tabular}




$\begin{array}{lll}\text { Mensintesis } & 40 \% & \text { Kurang } \\ \text { bukti } & & \text { Baik }\end{array}$

4 Menarik $\quad 30 \% \quad$ Tidak Baik

Kesimpulan

Berdasarkan tabel 2 menunjukkan bahwa pada soal no 1, terdapat $55 \%$ mahasiswa yang telah mencapai indikator menganalisis argumen, 45\% mahasiswa mencapai indikator mengevaluasi informasi, 40\% mahasiswa mencapai indikator mensintesis bukti dan 30\% mahasiswa mencapai indikator menarik kesimpulan.

Mahasiswa yang telah mencapai indikator menganalisis argumen sebanyak 11 mahasiswa menuliskan masalah yang terdapat pada soal. Mahasiswa menyatakan masalah tersebut dalam format penulisan diketahui, ditanya, dan dijawab agar mudah untuk dimengerti. Apa yang diketahui mahasiswa dituliskan pada sub diketahui, seperti bentuk lahan yang akan dibuka adalah segitiga siku-siku, segitiga tersebut dibagi menjadi dua bagian yang sama dan pada salah satu bagian dibagi lagi menjadi dua bagian membentuk dua segitiga siku-siku. Masalah yang dihadapi adalah menyebutkan sepasang segitiga yang sebangun.

Mahasiswa yang belum mencapai indikator menganalisis argumen sebanyak 9 mahasiswa. Tanpa menuliskan apa yang diketahui dan ditanya terlebih dahulu, namun langsung menggambar beberapa segitiga sembarang.

Berdasarkan wawancara yang dilakukan terhadap mahasiswa yang mencapai indikator terlihat bahwa memang tidak ada kebingungan. Mereka langsung menjelaskan melalui apa yang dia ketahui yaitu gambar segitiga sikusiku mereka dapat memulai menggambar segitiga yang lain. sedangkan mahasiswa yang belum mencapai indikator merasa tidak terlalu penting untuk menggambarkan segitiga pada soal karna itu tidak akan membantu dalam mengerjakan soal.

Sebanyak 9 mahasiswa yang mencapai indikator mengevaluasi informasi. Mahasiswa yang mencapai indikator mengevaluasi informasi adalah 
mahasiswa yang menuliskan informasi yang bermanfaat sebagai pendukung untuk mencari solusi. Mahasiswa terlebih dahulu membuat sketsa dari permasalahan yang ada.

Mahasiswa yang belum mencapai indikator mengevaluasi informasi sebanyak 11 mahasiswa. Mereka tidak menuliskan informasi-informasi yang ada pada uraian soal misalnya membuat sketsa gambar segitiga siku-siku sesuai intruksi.

Berdasarkan hasil wawancara menunjukkan bahwa anak yang tidak mencapai indikator merasa kebingungan untuk memahami soal. Mereka tidak tau apa yang harus mereka lakukan pada gambar yang sudah disediakan.

Indikator mensintesis bukti dicapai oleh 8 mahasiswa yang dapat menentukan banyak segitiga siku-siku yang sesuai dengan permasalahan. Banyak segitiga mereka ketahui dengan membuat sketsa gambar yang mereka buat dengan ketentuan pada soal. Melalui gambar segitiga inti yang disediakan kemudia mereka menambahkan garis-garis yang membagi segitiga tersebut menjadi beberapa bagian.

Mahasiswa yang tidak mencapai indikator sebanyak 12 mahasiswa. Mahasiswa tidak dapat menggambarkan garis-garis yang membagi segitiga inti sehingga mereka kebingungan dalam menentukan segitiga yang ada.

Mahasiswa yang mencapai indikator menarik kesimpulan sebanyak 6 mahasiswa. Mereka menuliskan jawaban atas perhitungan secara tepat sesuai dengan prosedur perhitungan. Sedangkan mahasiswa yang belum mencapai indikator menarik kesimpulan karna dari menentukan cara untuk menyelesaikan soal masih belum tepat sehingga dalam penarikan kesimpulanpun menjadi salah.

Mahasiswa yang tidak mencapai indikator sebanyak 14 mahasiswa. Dari 14 mahasiswa tersebut salah dalam membuat kesimpulan. Kesimpulan dibuat dengan asal-asalan tanpa memperhatikan kebenaran.

Berdasarkan hasil wawancara, mahasiswa yang mencapai indikator tidak merasa kesulitan dalam menentukan hasil penyelesaian karna mulai dari proses mensintesis sudah sesuai dan tepat. Sedangkan mahasiswa yang tidak mencapai indikator banyak yang salah dalam menentukan hasil akhir karena mereka dari 
proses awal memang sudah kesulitan. Hal ini disebabkan karna memang mereka tidak mengerti dan paham tentang sifat-sifat segitiga siku-siku. Sehingga dalam membuat sketsapun tidak tepat .

\section{Analisis Kemampuan Berpikir Kritis Soal No 2}

Berikut adalah hasil ketercapaian indikator keterampilan berpikir kritis pada soal no 2 yang disajikan pada tabel berikut:

Tabel 3. Hasil Ketercapaian Indikator Berpikir Kritis pada Soal 2

\begin{tabular}{|c|c|c|c|}
\hline $\mathrm{No}$ & $\begin{array}{l}\text { Indikator } \\
\text { Keemampuan } \\
\text { Perpikir } \\
\text { Kritis }\end{array}$ & $\begin{array}{l}\text { Jumlah } \\
\text { ketercapaian }\end{array}$ & Keterangan \\
\hline 1 & $\begin{array}{l}\text { Menganalisis } \\
\text { argumen }\end{array}$ & $55 \%$ & $\begin{array}{l}\text { Kurang } \\
\text { Baik }\end{array}$ \\
\hline 2 & $\begin{array}{l}\text { Mengevaluasi } \\
\text { Informasi }\end{array}$ & $30 \%$ & Tidak Baik \\
\hline 3 & $\begin{array}{l}\text { Mensintesis } \\
\text { bukti }\end{array}$ & $30 \%$ & Tidak Baik \\
\hline 4 & $\begin{array}{l}\text { Menarik } \\
\text { Kesimpulan }\end{array}$ & $30 \%$ & Tidak Baik \\
\hline
\end{tabular}

Berdasarkan tabel 3 menunjukkan bahwa ketercapaian kemampuan berpikir kritis pada soal no 2 , terdapat $55 \%$ mahasiswa yang telah mencapai indikator menganalisis argumen, 30\% mahasiswa mencapai indikator mengevaluasi informasi, mensintesis bukti dan menarik kesimpulan.

Mahasiswa yang telah mencapai indikator menganalisis argumen sebanyak 11 mahasiswa menuliskan perbandingan panjang kebun pak La Kane dan pak Jumadil yaitu 1:3, panjang kebun pak La Kane 15m dan 50 m. Pertanyaan dari soal adalah luas kebun pak Jumadil. Sedangkan mahasiswa yang tidak mencapai indikator menganalisis argumen sebanyak 9 mahasiswa hanya menuliskan panjang kebun pak La Kane $15 \mathrm{~m}$ dan $50 \mathrm{~m}$ tanpa menuliskan perbandingan sehingga informasi mengenai perbandingan antar kedua luas kebun tersebut diabaikan.

Mahasiswa yang mencapai indikator mengevaluasi informasi sebanyak 6 mahasiswa mampu mengidentifikasi hubungan pertanyaan dengan konsep dan 
model matematika. Dengan adanya informasi mengenai perbandingan antar kedua luas maka mahasiswa dapat menentukan konsep perbandingan pada penyelesaian soal. Mahasiswa yang tidak mencapai indikator mengevaluasi informasi sebanyak 14 mahasiswa. Tanpa menggunakan konsep perbandingan, mahasiswa hanya memanfaatkan panjang dan lebar yang telah diketahui.

Indikator mensintesis bukti dicapai oleh 6 mahasiswa yang mana mereka dapat menggunakan strategi yang benar dan mengaitkan konsep kesebangunan untuk menghitung luas. Sedangkan mahasiswa yang tidak mencapai indikator mengevaluasi informasi mereka tidak mampu mengaitkan kesebangunan untuk menghitung luas. Mereka cenderung menggunakan rumus luas maka dalam penyelesaian akan salah.

Mahasiswa yang mencapai indikator menarik kesimpulan sebanyak 6 mahasiswa. Mereka dalam menyelesaikan masalah dengan konsep algoritma yang benar atau sesuai langkah penyelesaiannya.

Berdasarkan hasil wawancara, mahasiswa yang mencapai indikator tidak merasa kesulitan dalam menentukan hasil penyelesaian karna mulai dari proses mensintesis sudah sesuai dan tepat.

\section{Analisis Kemampuan Berpikir Kritis Soal No 3}

Analisis ketercapaian indikator kemampuan berpikir kritis pada soal no 3. Berikut adalah hasil ketercapaian indikator keterampilan berpikir kritis pada soal no 3 yang disajikan pada tabel berikut

Tabel 4. Hasil Ketercapaian Indikator Berpikir Kritis pada Soal 3

\begin{tabular}{llll}
\hline No & $\begin{array}{l}\text { Indikator } \\
\text { Keemampuan } \\
\text { Perpikir } \\
\text { Kritis }\end{array}$ & $\begin{array}{l}\text { Jumlah } \\
\text { ketercapaian } \\
(\%)\end{array}$ & Keterangan \\
\hline 1 & $\begin{array}{l}\text { Menganalisis } \\
\text { argumen }\end{array}$ & $50 \%$ & $\begin{array}{l}\text { Kurang } \\
\text { baik }\end{array}$ \\
2 & $\begin{array}{l}\text { Mengevaluasi } \\
\text { Informasi } \\
\text { Mensintesis } \\
\text { bukti }\end{array}$ & $25 \%$ & Tidak Baik \\
& & Tidak baik \\
\hline
\end{tabular}




\begin{tabular}{llll}
\hline 4 & Menarik & $15 \%$ & Sangat \\
& Kesimpulan & & Tidak baik \\
\hline
\end{tabular}

Berdasarkan tabel 4 menunjukkan bahwa ketercapaian kemampuan berpikir kritis pada soal no 3, terdapat 50\% mahasiswa atau 10 mahasiswa yang telah mencapai indikator menganalisis argumen, 35\% atau 7 mahasiswa mencapai indikator mengevaluasi informasi, $25 \%$ atau 5 mahasiswa mencapai indikator mensintesis bukti dan $15 \%$ atau 3 mahasiswa mencapai indikator menarik kesimpulan.

Mahasiswa yang telah mencapai indikator menganalisis argumen sebanyak 10 mahasiswa memberikan tanda pada gambar yang memiliki sisi sama panjang dan mampu melihat sisi belah ketupat adalah sama panjang maka sisi yang bersesuaian pada kedua belah ketupat itu adalah sebanding.

Mahasiswa yang mencapai indikator mengevaluasi informasi sebanyak 7 mahasiswa menghubungkan kedua gambar belah ketupat dengan panjang sisinya.

Mahasiswa yang mencapai Indikator mensintesis bukti sebanyak 5 mahasiswa mampu menentukan sudut-sudut yang tidak bersesuaian yang tidak sama besar.

Mahasiswa yang mencapai indikator menarik kesimpulan sebanyak 3 mahasiswa menuliskan syarat sudut-sudut yang sebangun atau sudut yang bersesuaian, karena sudut yang sebangun adalah sudut yang sama besar. Sedangkan mahasiswa yang tidak mencapai indikator menarik kesimpulan sebanyak 17 mahasiwa membuat kesimpulan dengan asal-asalan

Hasil wawancara menunjukkan bahwa mahasiswa yang tidak mencapai indikator menarik kesimpulan merasa kesulitan karena mereka tidak mengetahui konsep kesebangunan. Banyak dari mereka yang menggunakan rumus manual dengan menghitung luas masing-masing kebun.

\section{Analisis Kemampuan Berpikir Kritis Soal No 4}

Analisis ketercapaian indikator kemampuan berpikir kritis pada soal no 4. Berikut adalah hasil ketercapaian indikator keterampilan berpikir kritis pada soal no 4 yang disajikan pada tabel berikut: 
Tabel 5. Hasil Ketercapaian Indikator Berpikir Kritis pada Soal 4

\begin{tabular}{llll}
\hline No & $\begin{array}{l}\text { Indikator } \\
\text { Keemampuan } \\
\text { Perpikir Kritis }\end{array}$ & $\begin{array}{l}\text { Jumlah } \\
\text { ketercapaian } \\
(\%)\end{array}$ & Keterangan \\
\hline 1 & $\begin{array}{l}\text { Menganalisis } \\
\text { argumen }\end{array}$ & $50 \%$ & Kurang baik \\
2 & $\begin{array}{l}\text { Mengevaluasi } \\
\text { Informasi }\end{array}$ & $40 \%$ & Kurang Baik \\
3 & Mensintesis bukti & $35 \%$ & Tidak Baik \\
4 & Menarik Kesimpulan & $35 \%$ & Tidak Baik \\
\hline
\end{tabular}

Berdasarkan tabel 5 menunjukkan bahwa ketercapaian kemampuan berpikir kritis pada soal no 4 , terdapat 50\% mahasiswa atau 10 mahasiswa yang telah mencapai indikator menganalisis argumen, $40 \%$ atau 8 mahasiswa mencapai indikator mengevaluasi informasi, 35\% atau 7 mahasiswa mencapai indikator mensintesis bukti dan indikator menarik kesimpulan.

Mahasiswa yang telah mencapai indikator menganalisis argumen sebanyak 10 mahasiswa menuliskan tinggi bayangan tiang $6 \mathrm{~m}$, panjang tongkat $2 \mathrm{~m}$. pertanyaan dari soal tersebut adalah tinggi tiang bendera.

Mahasiswa yang mencapai indikator mengevaluasi informasi sebanyak 8 mahasiswa membuat gambar atau sketsa dari permasalahan pada soal. Mahasiswa juga mengidentifikasi hubungan antar sketsa dengan model matematika.

Mahasiswa yang mencapai Indikator mensintesis bukti sebanyak 7 mahasiswa menentukan berapa tinggi tiang bendera dengan melihat sketsa dan memperhatikan segitiga dan sudut sehadap, sifat jumlah sudut-sudut dalam segitiga.

Mahasiswa yang mencapai indikator menarik kesimpulan sebanyak 7 mahasiswa menentukan semua sudut dalam segitiga yang sebangun atau berkorespondensi (bersesuaian) maka akan berlaku rumus perbandingan sehingga dapatlah hasil mencari tinggi tiang bendera.

\section{Analisis Kemampuan Berpikir Kritis Soal No 5}


Analisis ketercapaian indikator kemampuan berpikir kritis pada soal no 5. Berikut adalah hasil ketercapaian indikator keterampilan berpikir kritis pada soal no 5 yang disajikan pada tabel berikut:

Tabel 6. Hasil Ketercapaian Indikator Berpikir Kritis pada Soal 5

\begin{tabular}{llll}
\hline No & $\begin{array}{l}\text { Indikator Keemampuan } \\
\text { Perpikir Kritis }\end{array}$ & $\begin{array}{l}\text { Jumlah } \\
\text { ketercapaian } \\
(\%)\end{array}$ & Keterangan \\
\hline 1 & Menganalisis argumen & $65 \%$ & Baik \\
2 & $\begin{array}{l}\text { Mengevaluasi } \\
\text { Informasi }\end{array}$ & $40 \%$ & $\begin{array}{l}\text { Kurang } \\
\text { baik }\end{array}$ \\
3 & Mensintesis bukti & $25 \%$ & $\begin{array}{l}\text { Tidak baik } \\
4\end{array}$ \\
\hline
\end{tabular}

Berdasarkan tabel 6 menunjukkan bahwa ketercapaian kemampuan berpikir kritis pada soal no 4 , terdapat $65 \%$ mahasiswa atau 13 mahasiswa yang telah mencapai indikator menganalisis argumen, $40 \%$ atau 8 mahasiswa mencapai indikator mengevaluasi informasi, $25 \%$ atau 5 mahasiswa mencapai indikator mensintesis bukti dan $20 \%$ atau 4 mahasiswa mencapai indikator menarik kesimpulan.

Mahasiswa yang telah mencapai indikator menganalisis argumen sebanayak 13 mahasiswa menuliskan yang dibutuhkan untuk memecahkan masalah yaitu ukuran meja makan $4 \times 3 \mathrm{~m} 2$, meja kantor sebangun dengan meja makan dsn perbandingannya 5:2, harga taplak meja Rp 37.500,00 per m2. Sedangkan mahasiswa yang belum mencapai indikator hanya menuliskan yang ingin ditanyakan saja apakah ukuran meja kantor dan biaya untuk membeli taplak kedua meja tersebut.

Mahasiswa yang mencapai indikator mengevaluasi informasi sebanayak 8 mahasiswa menentukan permasalahan pada soal ke dalam sketsa atau gambar sehingga dapat alternatif untuk menghubungkan pertanyaan tersebut dengan konsep-konsep kesebangunan.

Mahasiswa yang mencapai Indikator mensintesis bukti sebanyak 5 mahasiswa menentukan alternatif konsep-konsep kesebangunan. 
Mahasiswa yang mencapai indikator menarik kesimpulan sebanayak 4 mahasiswa menentukan penyelesaian dari permasalahan yang ditanyakan dengan mengidentifikasi hubungan dengan alternatif rumus kesebangunan dalam perbandingan.

\section{Pembahasan}

Hasil analisis data penelitian menunjukkan bahwa kemampuan berpikir kritis pada indikator menganalisis argumen kategori kurang. Kemampuan berpikir kritis pada indikator mengevaluasi informasi kategori tidak baik. Kemampuan berpikir kritis pada indikator mensintesis bukti kategori tidak baik. Kemampuan berpikir kritis pada indikator menarik kesimpulan kategori tidak baik. Hasil penelitian yang dilakukan sesuai dengan penelitian yang dilakukan oleh Lela Nur Safrida dalam penelitiannya tentang analisis kemampuan berpikir kritis mahasiswa program studi pendidikan matematika yang mengukur kemampuan berpikir kritis mahasiswa berdasarkan empat indikator berpikir kritis yaitu kemampuan mensintesis argumen, mengevaluasi informasi, mensintesis bukti, dan menarik kesimpulan. Sehingga kesimpulan dari penelitian ini adalah kemampuan berpikir kritis mahasiswa PGSD perlu untuk dikembangkan.

\section{Simpulan}

Isi simpulan dan rekomendasi wajib ada, ditulis dengan paragraf, tidak dengan nomor. Rekomendasi yang dituliskan adalah rekomendasi penelitian.

Berdasarkan hasil penelitian dan pembahasan, dapat disimpulkan bahwa secara umum tingkat kemampuan berpikir kritis mahasiswa pada indikator menganalisis argumen tergolong masih kurang, indikator mengevaluasi informasi tergolong tidak baik, ketercapaian indikator mensintesis bukti dalam kategori tidak baik, dan ketercapaian indikator menarik kesimpulan tergolong tidak baik pada mata kuliah konsep dasar matematika. Dengan demikian kemampuan berpikir kritis mahasiswa PGSD pada mata kuliah konsep dasar matematika perlu untuk dikembangkan.

Berdasarkan temuan dari penelitian ini maka disarankan untuk dosen mata kuliah konsep dasar matematika agar dapat : (1) melakukan perbaikan 
terhadap pembelajaran konsep dasar matematika di prodi PGSD. (2) meningkatkan pemahaman konsep matematika dasar mahasiswa.

\section{Daftar Pustaka}

Baxter, C. (1997). Race Equality in Health Care and Education. Philadelphia: Balliere Tindal.

Clark, L.A., Konchanska, G., \& Ready, R. (2000). Mothers' Personality and Its Interaction with Child Temperament as Predictors of Parenting Behavour. Journal of Personality and Social Psycology Vol. 1 (2), 274-285.

Dunkin, M.J. dan Biddle, B.J. (1974). The Study of Teaching. New York: Holt Rinehart and Winston.

Ennis, Robert H.(1985). Critical Thinking. New Jersey : Prentice Hall, University of lllinois

Hassoubah,I.J.(2004). Cara Berpikir Kreatif dan Kritis. Bandung: Nuansa

Lai, Emily R.(2011). Critical Thinking: A Literature Review. Pearson's Re-search Reports.

Lela Nur Safrida dkk.(2018). Analisis Kemampuan Berpikir Kritis Mahasiswa Program Studi Pendidikan Matematika. Jurnal Pendidikan Matematika, 6(1), 1016

Maryam, R. Siti, dkk. (2008). Mengenal usia lanjut dan perawatannya. Jakarta: Salemba Medika.

Rubenfelt M.G dan Scheffer, B.K. (2006). Berfikir Kritis Keperawatan Edisi 2. Jakarta: EGC

Rasiman.(2012). Penelusuran Proses Berpikir Kritis dalam Menyelesaikan Masalah Matematika Bagi Siswa dengan Kemampuan Matematika Tinggi. e-Journal Matematika dan Pendidikan Matematika, 3(1)

- Proses Berpikir Kritis Siswa SMA dalam Menyelesaikan Masalah

Matematika Bagi Siswa dengan Kemampuan Matematika Rendah, Prosiding Seminar Nasional Matematika dan Pendidikan Matematika. ISSN 978 - 979 $16353-9-4$,

\& Kartinah.(2015). Penjenjangan Kemampuan Berpikir Kritis Mahasiswa Prodi Pendidikan Matematika FPMIPA IKIP PGRI Semarang dalam Menyelesaikan Masalah Matematika, dalam 
http://eprints.upgrismg.ac.id/33/1/I.\%20MAKALAH\%20KIRIM\%20UN S2013-uns-eprints.pdf, diakses 20 April 2015

Sugiyono.(2013). Metodologi Penelitian Kuantitatif Kualitatif dan $R$ dan $D$. Bandung: Alfabeta 